\title{
Evaluation of knowledge of Oral Health of Community Health Agents connected with the Family Health Strategy
}

\author{
Giovana Renata Gouvêa ${ }^{1}$ \\ Marco Antônio Vieira Silva ${ }^{1}$ \\ Antônio Carlos Pereira ${ }^{1}$ \\ Fábio Luiz Mialhe ${ }^{1}$ \\ Karine Laura Cortellazzi ${ }^{1}$ \\ Luciane Miranda Guerra
}

${ }^{1}$ Departamento de Odontologia Social, Faculdade de Odontologia de Piracicaba, Universidade Estadual de Campinas. Av. Limeira 901, Areão. 13414-903 Piracicaba São Paulo Brasil.

gigouvea@hotmail.com
Abstract The aim of this study was to evaluate the knowledge of Community Health Agents (CHA) about the oral health/disease process, and compare the results between those who work in Family Health Teams (FHT), with and without Oral Health Teams (OHT). The participants in this study were 162 subjects, representing 66\% of the total number of CHA in the municipality, and 81 of them are connected with Family Health Units (FHU) with OHT, and 81 CHS with FHUs without OHT. Data were collected from October to December 2013, by application of a questionnaire, containing personal and professional data, and 12 validated questions about knowledge of the oral health/disease process. The Mann-Whitney test was applied to verify differences between the groups. Statistically significant differences were verified between the groups of CHA when the total scores of questions about the oral health/ disease process were analyzed $(p<0.0021)$. It was concluded that knowledge about the oral health/ disease process, of the CHAs connected with a FHU with an OHT was better when compared with that of CHAs connected with a FHU without an OHT.

Key words Oral health Education, Community Health Agent, Family Health Strategy 


\section{Introduction}

In Brazil, the Community Health Agents (CHA) participate actively in the organization of family health care at the primary care level, by registering families and paying them, individuals and or priority groups of persons ${ }^{1}$ monthly follow-up visits. They also play an important role in disseminating information about oral health, and must be guided by the above-mentioned Team ${ }^{2}$. These professionals are included in health systems in different parts of the world, such as the United States of America ${ }^{3}$, Kenya ${ }^{4}$, Bangladesh ${ }^{5}$, the United Kingdom ${ }^{6}$, South Africa ${ }^{7}$, and Brazil ${ }^{8}$, among others.

In the view of managers and service providers, the central task of CHAs is simply to pass on informal guidance about the health of the population they visit, and in the opinion of many users of these services, their purpose is mainly to facilitate access to the Family Health Unit ${ }^{9}$. But the CAHs are fundamental actors/players in the Family Health Strategy (FHS), because they are closer to the problems that affect the community, and because they are the professionals that construct and strengthen the link between the community and Health Team, in addition to being outstanding by their born leadership qualities and ease in communicating with members of the community. Therefore, to simplify their role in health is, at the very least, to lack knowledge of the advancement their work provides to SUS ${ }^{10}$.

The implementation of Oral Health Teams (OHTs) has brought with it, new approaches to CHAs, among them the understanding of oral health as a component of health in its broadest expression ${ }^{11}$. However, it is important to argue that the greater appreciation given to promotional actions in clinical and collective spaces could also be attributed to the CHAs, and duly qualified multipliers, professionals who form part of the Family Health Teams ${ }^{12}$.

Thus, the CHAs play a fundamental role in the process of oral health education, by virtue of the priority of their work in the field, enabling them to spontaneously anticipate the demand ${ }^{13}$. The presence of dental surgeons in the Family Health Units (FHU) may open new horizons and greater assurance to the work of CHAs, and all this requires is that the interdisciplinary concept leads to the process of teamwork ${ }^{14}$.

To Santos ${ }^{15}$, demonopolization of dental knowledge and taking it into the homes of families, would contribute to increasing the independence of the population and its co-responsibil- ity for the preservation and promotion of oral health conditions, in a process of articulating oral health with the general health of persons.

For this reason, the command of knowledge about oral health by CHAs, when compatible with their education and the scope of their functions, presents great social relevance, to the extent to which their work allows the adoption of educational measures that benefit a larger number of persons in a relatively short time. It is also important to consider that the fact of belonging to the community in which they perform their activities, places the CHAs in conditions to understand the set of predominant beliefs and concepts in the community, many of which are not compatible with scientific knowledge ${ }^{13}$.

In the majority of instances, health teams still develop Health Education in a biologistic, mechanical and acritical manner, in spite of the recent methodological and theoretical reorientation $^{16}$.

Among the attributes common to all Family Health Team professionals, are those of performing interdisciplinary work and working as a team, integrating the technical and professional areas of different types of education, and performing actions of health education in the population described above, according to the planning of the team ${ }^{1}$. The attributes of the dental surgeon, in addition to those within the clinical sphere, are to coordinate and participate in collective actions directed towards health promotion and the prevention of oral diseases, following-up, supporting and developing activities with reference to oral health together with the other members of the team, thus seeking to approximate and integrate actions of health in a multidisciplinary manner ${ }^{2}$.

Although there are no previous studies with respect to the knowledge of CHAs about the health-disease process and presence of the oral health team, there are data that provided a basis for the interference of dentists and their assistants in the work of CHAs. Frazão and Marques ${ }^{14}$ observed positive changes with regard to oral health aspects, self-confidence and to the access and use of services by CHAs who underwent training together with an oral health team.

On the other hand, the original education of CHAs, initially linked to the categories of nursing and medicine, contributes towards distancing the relations between dentists and CHAs, even when they are connected with the same FHU. This may compromise education and make it difficult to perform oral health activities between them, which make them less effective ${ }^{17}$. 
Bearing in mind the importance of CHAs' in training in Oral Health by Dentists, and the absence of studies comparing the knowledge of CHAs connected with FHUs, with and without Oral Health Teams, the aim of this study was to evaluate the knowledge of CHAs' in Piracicaba/ SP, about the oral health-disease process, and compare the results with those of CHAs who work in FHUs with and without OHTs.

From this perspective, the present study increments the present state of the art of oral health education, to the extent to which it allows optimization of pedagogical and educational processes coherent with the reality, profile and context of these professionals, by revealing factors that may have an impact on the effectiveness of training CHAs.

\section{Material and Methods}

The present study, of a qualitative nature, was conducted in the municipality of Piracicaba, situated at a distance of $165 \mathrm{~km}$ from the capital São Paulo. Piracicaba has a total territorial area of $1,370 \mathrm{~km}^{2}$ and an estimated population of 385 287 inhabitants, with $95 \%$ of them concentrated in the urban area $^{18}$.

The research began only after consent of the Municipal Secretary of Health and approval of the Research Ethics Committee of the Piracicaba Dental School, University of Campinas, had been obtained.

By means of the System of Information to the Citizen of Piracicaba, it was verified that in the period of the research, there were 245 active Community Health Agents in the municipality. In the research, all of them were approached, but as some of the CHAs were on vacation, sick leave, maternity leave, or were not interested in participating during the period of the research, the census sample was composed of 162 CHAs, representing $66 \%$ of this population. The sample was divided into 2 groups, with Group 1 being composed of 81 CHAs coming from 17 Family Health Units without Oral Health Teams, and Group 2, with 81 CHAs coming from 20 Family Health Units with Oral Health Teams, consisting of a total of 37 FHS out of the 46 existent in the municipality.

The criteria for inclusion of the CHAs in the study were as follows: having signed the Term of Free and Informed Consent (TFIC), and being an effectively hired Community Health Agent.

The study variables were: gender, age, educational level, time of residence in the suburb, family income, time of working as CHA, and knowl- edge about the oral health-disease process.

The data were collected by means of a semi-structured questionnaire, by a single researcher, in the period between October and December 2013. The questionnaire was applied at the FHU during weekly team meetings held as part of management routine. When this was not possible, the second strategy opted for was to telephone previously and schedule appointments on days and at times that would not interfere in the CHAs' processes of work.

The questionnaire contained questions about personal characteristics, socioeconomic conditions of the research subjects, and twelve validated questions about knowledge of the oral health-disease process $^{14}$. Differentiated values were attributed to each response, as used in the study of Bianco ${ }^{13}$, adopting the principles of benefit and not harm as criterion, used within the scope of the prinicipalist paradigm of bioethics ${ }^{19}$.

According to Bianco ${ }^{13}$ if responses are selected, which may give rise to behaviors that do not improve the conditions of health of a person in any way, or when these responses indicate that the individual may use his/her knowledge to adopt a procedure, which in any way, may cause harm to his/her oral health condition, such responses are considered without score (zero value).

Chart 1 presents the results with reference the questions on the form of the original research, with respective scores, which consisted of 12 questions,with a variation of four to six alternative responses, to which the value of the score attributed was from 0 to 5 , according to the above-mentioned criteria. The maximum score of the sum of the twelve questions was 41 and the minimum, 0 .

Therefore, the intention was to present the respondent with a set of response options, so that he/she could choose the response that best represented his/her situation or perception of oral health ${ }^{20}$.

The data were transcribed from the questionnaires to the Microsoft Excel 7.0. software program. For statistical analysis of the results, the software program BioEstat 5.0. was used. Initially, descriptive analysis of data was performed by means of absolute and relative frequencies.

For evaluation of the statistical significance of differences in the scores that were obtained by the individuals in the sample of CHAs of Group 1 in comparison the the sample of CHAs of Group 2, the Mann-Whitney test for two independent samples was applied, considering the level of significance of $5 \%$. 
Chart 1. Value attributed to the responses for each question in the research form.

\begin{tabular}{|c|c|c|}
\hline & Response Alternatives & $\begin{array}{c}\text { Value } \\
\text { attributed }\end{array}$ \\
\hline $\begin{array}{l}\text { In your perception, with } \\
\text { regard to primary } \\
\text { teeth, which option do you } \\
\text { consider correct? }\end{array}$ & $\begin{array}{l}\text { a. because they are temporary teeth, they don't need care } \\
\text { b. they guide the eruption or "birth" of permanent teeth } \\
\text { c. they appear in the mouth when the mother stops } \\
\text { breastfeeding the baby } \\
\text { d. they are teeth that fall out easily because they have no roots } \\
\text { e. did not know/did not inform }\end{array}$ & $\begin{array}{l}0 \\
2 \\
0 \\
1 \\
0\end{array}$ \\
\hline $\begin{array}{l}\text { From birth up to } \\
\text { adult age, how many times } \\
\text { are the teeth changed? }\end{array}$ & $\begin{array}{l}\text { a. Once } \\
\text { b. Twice } \\
\text { c. three, including the wisdom tooth } \\
\text { d. did not know/did not inform }\end{array}$ & $\begin{array}{l}3 \\
2 \\
1 \\
0\end{array}$ \\
\hline $\begin{array}{l}\text { In your opinion, at what age } \\
\text { do the first permanent teeth } \\
\text { start erupting? }\end{array}$ & $\begin{array}{l}\text { a. at around } 6 \text { months to } 1 \text { year } \\
\text { b. From } 2 \text { to } 3 \text { years } \\
\text { c. From } 5 \text { to } 6 \text { years } \\
\text { d. From } 8 \text { to } 9 \text { years } \\
\text { e. From } 11 \text { to } 12 \text { years }\end{array}$ & $\begin{array}{l}0 \\
0 \\
2 \\
1 \\
0\end{array}$ \\
\hline $\begin{array}{l}\text { What is your perception as } \\
\text { regards the main cause of } \\
\text { strong dentition }\end{array}$ & $\begin{array}{l}\text { a. inheritance from parents (birth) } \\
\text { a. types of race } \\
\text { b. good financial condition } \\
\text { c. care with oral hygiene and diet } \\
\text { d. did not know/did not inform }\end{array}$ & $\begin{array}{l}2 \\
3 \\
1 \\
4 \\
0\end{array}$ \\
\hline $\begin{array}{l}\text { To you, is caries a disease } \\
\text { mainly caused by: }\end{array}$ & $\begin{array}{l}\text { a. poor formation of the structure of teeth } \\
\text { b. bacteria adhered to the teeth } \\
\text { c. constant use of antibiotics } \\
\text { d. lack of saliva in the mouth } \\
\text { e. frequent ingestion of sugary products } \\
\text { f. did not know/did not inform }\end{array}$ & $\begin{array}{l}1 \\
2 \\
0 \\
3 \\
4 \\
0\end{array}$ \\
\hline $\begin{array}{l}\text { In the majority of cases, bad } \\
\text { breath (halitosis) is caused } \\
\text { by: }\end{array}$ & $\begin{array}{l}\text { a. emotional stress } \\
\text { b. Use of Medications } \\
\text { c. smoking and excessive alcohol consumption } \\
\text { d. failure to remove bacterial plaque that accumulates on the } \\
\text { teeth and tongue } \\
\text { e. Sugary and fatty foods } \\
\text { f. did not know/did not inform }\end{array}$ & $\begin{array}{l}2 \\
1 \\
4 \\
5 \\
3 \\
0\end{array}$ \\
\hline $\begin{array}{l}\text { Do you think gingival } \\
\text { bleeding is: }\end{array}$ & $\begin{array}{l}\text { a. normal and always occurs with tooth brushing } \\
\text { b. the greatest cause of dental caries } \\
\text { c. an infection that affects the nerve of the tooth } \\
\text { d. the first sign of gingival disease } \\
\text { e. did not know/did not inform }\end{array}$ & $\begin{array}{l}0 \\
2 \\
1 \\
3 \\
0\end{array}$ \\
\hline $\begin{array}{l}\text { In order to prevent gingivitis } \\
\text { it is necessary to perform oral } \\
\text { hygiene procedures, correctly } \\
\text { using: }\end{array}$ & $\begin{array}{l}\text { a. toothbrush only } \\
\text { b. tooth brush and toothpaste with fluoride } \\
\text { c. Toothbrush and dental floss } \\
\text { d. Special liquids for mouth washes and fluoride solutions } \\
\text { e. did not know/did not inform }\end{array}$ & $\begin{array}{l}2 \\
3 \\
4 \\
1 \\
0\end{array}$ \\
\hline
\end{tabular}




\begin{tabular}{|c|c|c|}
\hline \multicolumn{3}{|l|}{ Chart 1. continuation } \\
\hline & Response Alternatives & $\begin{array}{c}\text { Value } \\
\text { attributed }\end{array}$ \\
\hline $\begin{array}{l}\text { In your opinion, indicate the } \\
\text { alternative that could lead } \\
\text { to the tooth needing canal } \\
\text { treatment: }\end{array}$ & $\begin{array}{l}\text { a. untreated caries lesion } \\
\text { b. excessive fluoride } \\
\text { c. use of broken denture } \\
\text { d. poorly fitting removable bridge } \\
\text { e. did not know/did not inform }\end{array}$ & $\begin{array}{l}4 \\
1 \\
2 \\
3 \\
0\end{array}$ \\
\hline $\begin{array}{l}\text { During pregnancy, do you } \\
\text { think that dental treatment } \\
\text { should be: }\end{array}$ & $\begin{array}{l}\text { a. preventive and periodical } \\
\text { b. avoided throughout the entire pregnancy } \\
\text { c. for cases of urgency } \\
\text { d. did not know/did not inform }\end{array}$ & $\begin{array}{l}2 \\
0 \\
1 \\
0\end{array}$ \\
\hline Fluoride is important: & $\begin{array}{l}\text { a. only in childhood, at the time of formation and eruption of } \\
\text { teeth } \\
\text { b. in adult life } \\
\text { c. in elderly persons } \\
\text { d. at all stages of life } \\
\text { e. did not know/did not inform }\end{array}$ & $\begin{array}{l}3 \\
2 \\
1 \\
4 \\
0\end{array}$ \\
\hline $\begin{array}{l}\text { In your perception, indicate } \\
\text { the alternative that cites the } \\
\text { risk factor most related to the } \\
\text { appearance of oral cancer: }\end{array}$ & $\begin{array}{l}\text { a. ingestion of medications } \\
\text { b. diet rich in salt and sugar } \\
\text { c. excess consumption of alcohol and tobacco } \\
\text { d. loss of permanent teeth } \\
\text { e. did not know/did not inform }\end{array}$ & $\begin{array}{l}1 \\
2 \\
4 \\
3 \\
0\end{array}$ \\
\hline
\end{tabular}

Source: Bianco, 201013.

\section{Results}

The groups were homogeneous with regard to socioeconomic variables $(p>0.05)$. In Table 1 the results of the frequency of CHAs per group and their distribution according to gender, age, educational level, time of residence in the suburb, family income and time of work in FHU, are presented.

The results bout the knowledge of the oral health-disease process demonstrated that the CHAs connected with a FHU with an Oral Health Team in Piracicaba, in general presented a higher level of knowledge, when compared with the group of CHAs connected with a FHU without an Oral Health Team in Piracicaba. The first question sought to reveal the perception of the CHAs with regard to primary dentition. The individuals in the sample connected with a FHU without and with and OHT obtained a score of 155 and 147, respectively, out of a possible total score of 162 .
In the comparison made between CHAs connected with a FHU without and with OHT, about the question that asked the number of times a person changes dentition, the professionals attained scores of 181 and 199, respectively, but could have obtained up to 243 . The following question dealt with the age at which permanent teeth erupted. The samples composed of CHAs could have obtained a total score of 162 . Therefore the score attained in the group of CHAs connected with a FHU without and with an OHT were 117 and 120, respectively.

The result of the next question, related to the main cause of caries, demonstrated statistically significant difference between the two samples of CHAs (Table 2).

In Group 1, composed of CHAs connected with a FHU without OHT, a score of 210 was verified; that is, $64.81 \%$ out of a possible total of 324 . In Group 2, composed of CHAs connected with a FHU with an OHT, a score of 248 (76.54\%) was verified. After the statistical test, $\mathrm{p}=0.0149$ was 
Table 1. Frequency of Community Health Agents (CHAs) and their distribution according to gender, age, education, time of residence in suburb, family income, time of work at Family Health Unit (FHU) Piracicaba, 2013.

\begin{tabular}{|c|c|c|c|}
\hline & Group 1 & Group 2 & \\
\hline Variables & $\begin{array}{c}\text { CHA in FHU without Oral } \\
\text { Health Team } \\
\mathbf{n}\end{array}$ & $\begin{array}{c}\text { CHA in FHU with Oral } \\
\text { Health Team } \\
\mathbf{n}\end{array}$ & p-value \\
\hline Total & 81 & 81 & \\
\hline Gender & & & 0.4427 \\
\hline Male & $5(6.2 \%)$ & $2(2.5 \%)$ & \\
\hline Female & $76(93.8 \%)$ & $79(97.5 \%)$ & \\
\hline Age & & & 0.1431 \\
\hline less than 20 & $0(0.0 \%)$ & $0(0.0 \%)$ & \\
\hline $20-29$ years & $19(23.4 \%)$ & $20(24.7 \%)$ & \\
\hline $30-39$ years & $25(30.9 \%)$ & $37(45.7 \%)$ & \\
\hline 40-49 years & $22(27.2 \%)$ & $16(19.7 \%)$ & \\
\hline 50 years or older & $15(18.5 \%)$ & $8(9.9 \%)$ & \\
\hline Educational level & & & 0.5256 \\
\hline Complete Primary Schooling & $2(2.5 \%)$ & $0(0.0 \%)$ & \\
\hline Incomplete Primary Schooling & $0(0.0 \%)$ & $0(0.0 \%)$ & \\
\hline Complete High Schooling & $52(64.2 \%)$ & $52(64.2 \%)$ & \\
\hline Incomplete High Schooling & $5(6.2 \%)$ & $8(9.9 \%)$ & \\
\hline Completed College Education & $7(8.6 \%)$ & $4(4.9 \%)$ & \\
\hline Incomplete College Education & $15(18.5 \%)$ & $17(21.0 \%)$ & \\
\hline Time of residence in Suburb & & & 0.2155 \\
\hline Less than 12 months & $0(0.0 \%)$ & $0(0.0 \%)$ & \\
\hline 12 to 24 months & $0(0.0 \%)$ & $3(3.7 \%)$ & \\
\hline From 25 to 36 months & $4(4.9 \%)$ & $1(1.2 \%)$ & \\
\hline From 37 to 48 months & $5(6.2 \%)$ & $4(4.9 \%)$ & \\
\hline Longer than 48 months & $72(88.9 \%)$ & $73(90.2 \%)$ & \\
\hline Family Income & & & 0.1400 \\
\hline Less than $1 \mathrm{MW}$ & $0(0.0 \%)$ & $0(0.0 \%)$ & \\
\hline From 1 to less than $2 \mathrm{MW}$ & $14(17.3 \%)$ & $12(14.8 \%)$ & \\
\hline From 2 to less than $3 \mathrm{MW}$ & $19(23.5 \%)$ & $19(23.5 \%)$ & \\
\hline From 3 to less than $4 \mathrm{MW}$ & $13(16.0 \%)$ & $21(25.9 \%)$ & \\
\hline From 4 to less than $5 \mathrm{MW}$ & $15(18.5 \%)$ & $20(24.7 \%)$ & \\
\hline Over $5 \mathrm{MW}$ & $20(24.7 \%)$ & $9(11.1 \%)$ & \\
\hline Time of work at FHU & & & 0.4293 \\
\hline Less than 12 months & $1(1.2 \%)$ & $1(1.2 \%)$ & \\
\hline 12 to 24 months & $8(9.9 \%)$ & $10(12.4 \%)$ & \\
\hline From 25 to 36 months & $13(16.1 \%)$ & $21(25.9 \%)$ & \\
\hline From 37 to 48 months & $12(14.8 \%)$ & $13(16.1 \%)$ & \\
\hline Longer than 48 months & $47(58.0 \%)$ & $36(44.4 \%)$ & \\
\hline
\end{tabular}

Table 2. Distribution of Groups of Community Health Agents (CHA) according to question 12: "To you, is caries a disease mainly caused by:" Piracicaba, 2013.

\begin{tabular}{lcc}
\hline \multicolumn{1}{c}{ Score } & $\begin{array}{c}\text { CHA in FHU without } \\
\text { Oral Health Team }\end{array}$ & $\begin{array}{c}\text { CHA in FHU with } \\
\text { Oral Health Team }\end{array}$ \\
\hline $\begin{array}{l}\text { Maximum individual score of question } \\
\text { Total Score of question }\end{array}$ & 4 & 4 \\
\hline
\end{tabular}

$p=0.0149$ 
verified; that is, the difference was statistically significant.

The knowledge of the two samples of CHAs about the appearance of bad breath was approached in the questionnaire. A total score of 405 could be obtained. The group of individuals in the sample of CHAs connected to a FHU without and with OHT, obtained scores of 311 and 316 , respectively.

The next question dealt with gingival bleeding. The result presented by the sample of CHAs connected with a FHU without OHT showed a total score equal to 229. The sample of CHAS connected with a FHU with an OHT obtained a score of 217, out of a possible total score of 243.

In the data with reference to the adoption of oral hygiene procedures as a measure to prevent gingival bleeding, out a possible total score of 324, the individuals in the sample of CHAs connected with a FHU without OHT obtained a score of 284. This value was 303 in the case of the sample of CHAs connected with a FHU with an OHT.

In the only question that approach the need for endodontic treatment, the results were identical for the two groups, who obtained a score of 320 .

In the question approaching the pertinence of dental procedures during gestation, the CHAs of Group 1, as a set, achieved an absolute score equal to 154 our of a possible 162 . Whereas the CHAs of Group2 presented a score of 161 out of a possible 162 .

The age at which fluoride could protect the dentition of persons was the theme of the next question.

The individuals representative of the CHAs connected with a FHU without OHT obtained a score of 299, and those connected with a FHU with an OHT obtained a total score of 295, out of a possible total score of 324 .

The last question in the questionnaire applied in the study sought to relate oral cancer $t$ some previous conditions. The sample of CHAS connected with a FHU without an OHT obtained a score of 289 , out of a possible total score of 324 . The score of 303 was presented by the sample of CHAS connected with a FHU with an OHT, out of a possible total score of 324 .

The CHAS connected with a FHU without an OHT, as a set, attained a total score of the questionnaire equal to 2864 out of a possible 3321 . Therefore, in terms relative to performance, they attained $86.24 \%$. Whereas, the CHAS connected with a FHU with an OHT, as a set, attained a total score of the questionnaire equal to 2946 out of a possible 3321, achieving a performance of $88.71 \%$ of the total.

There was significant difference between the samples of CHAs connected to a FHU without an OHT, and CHAs connected with a FHU with an OHT, when the total score of the questionnaire was analyzed (Table 3).

\section{Discussion}

This study started with the hypothesis that the Oral Health Team connected with the Family Health Unit could contribute to an increase in the knowledge of CHAs about the oral health/ disease process.

As regards the characteristics of the sample, in the present study a predominance of the female gender was verified. A similar ratio was found in the study of Vasconcelos et al. ${ }^{21}$, conducted among CHAs in the municipality of Virgem da Lapa/Minas Gerais, where the authors verified a similar predominance, being $92 \%$ of the sample universe of the research.

Another study conducted in 10 Brazilian cities verified that over $75 \%$ of the CHAs were of the female sex ${ }^{22}$. In Porto Velho/Rondônia, Bian$\mathrm{Co}^{13}$ verified that $84 \%$ of the CHAs who worked there were of the female sex. The work of CHAs

Table 3. Distribution of Groups of Community Health Agents (CHA) according to Knowledge of Oral Health Piracicaba, 2013.

\begin{tabular}{lcc}
\hline & CHA in FHU without Oral Health Team & CHA in FHU with Oral Health Team \\
\hline Score & 81 & 81 \\
Maximum Value & 41 & 41 \\
Minimum Value & 26 & 20 \\
Median & 36 & 37 \\
\hline
\end{tabular}

$p=0.0021$ 
is recognizably associated with female domestic work, which has a historically recognized inclination towards health care. On the other hand, work close to one's home and be able to control and accompany the daily life of one's children, particularly when they are of school-going age, may represent an advantage to these women, which exceeds the low salaries and precarity. In this sense, there is expressive predominance of women in the work of CHAs throughout the country ${ }^{23}$.

Concerning the educational level, $64.20 \%$ of the CHAs were observed to have complete middle school education, a level of schooling above that demanded by the Ministry of Health for performing the activity, which is Primary schooling $^{24}$. Further to this social characteristic of the CHAs, attention is drawn to the fact that over $26 \%$ of the individuals declared that they had concluded higher education, or were doing higher educational courses. Of these $26 \%, 15 \%$ have taken courses, or are taking courses in the Area of health at higher educational level, in spite of a career plan not occurring in the job of CHA.

Bachilli et al. ${ }^{25}$ have discussed the issue that on becoming a member of the Family Health Team, the CHA gains access to technical-scientific knowledge through training and being in contact with other professionals of the tea, which ends up encouraging the CHA to attain a higher degree in the area. The rise in the educational level found in this study is considered positive, since the its reflection may favor processes of interaction with the community and team, in addition to broadening the critical ability and creativity of the worker ${ }^{26}$.

As regards the characteristics of time of residence in the Suburb and length of time working as $\mathrm{CHA}$, one perceives that the large majority of the interviewees in the present study had resided in the suburb and worked as CHA longer than 25 months A fact to be pointed out is that $89.51 \%$ responded that they had resided in the suburb for over 5 years, a result similar to that in the study of Marques ${ }^{27}$, in which $93.8 \%$ had resided in the place for over 5 years. With regard to the interpersonal relationship with, and tie to the community, the CHAs are the only workers in the Primary Care health team that must reside in the place in which they work for a minimum of two years, in compliance with the demands established by the Ministry of Health ${ }^{24}$.

However, in the study of Ursine et al. ${ }^{28}$, the mean time of residence in the place where they performed the function was 16.1 years, and the time of activity as CHA varied from 0.5 to 9 years, with a mean of 4 years. Residing for a long time in the suburb in which one works makes it easier for the population to receive this professional in his/her work routine.

Certainly, the high mean time of activity in the same health unit and living in the same place of work may have a positive influence on articulating the service with the community and in coping with the complexity of work in the health area. The time of residence may be a factor that influences the quality of the relationship between agent and the community, because people consider the agent a neighbor even before being a $\mathrm{CHA}$, since they frequent the same social spaces and have access to his/her house. There are also other important aspects to consider, such as the empathy involved in the integration of this worker with the users and the efficient performance of his/her work ${ }^{29}$.

As regards the knowledge of the oral health/ disease process, specifically related to primary dentition (Question 1), the present study exceeded the percentage found in the study of Frazão e Marques ${ }^{14}$, in which only $43.8 \%$ of the CHAs checked the expected response. The early loss of primary teeth may result in serious consequences for the permanent dentition, and may lead to the development of atypical swallowing and phonation, causing delay or acceleration in the eruption of permanent teeth, making it difficult for the child to eat and favoring the onset of probable orthodontic problems, in addition to affecting the child psychologically ${ }^{30}$.

When we observed the scores of the same question, comparing the group of CHAs connected with the FHU without an OHT, the CHAs connected with a FHU with an OHT, the professionals obtained means scores of 2.23 and 2.46 respectively, out of a maximum score of 3 . The mean score obtained by the group with an Oral Health Team was identical to the result found in the study of Bianco ${ }^{13}$.

The time of eruption of the first permanent teeth showed no statistically significant difference between Groups 1 and 2. It was found that $69.14 \%$ of the CHAs in Group 1 and $65.43 \%$ of the CHAs in Group 2, checked the expected response. A different result occurred in the study of $\mathrm{Barba}^{31}$, in which $100 \%$ of the CHAs indicated the period from five o seven years as the beginning of eruption of permanent teeth.

The basic eruption and chronology of dentitions mus be included as topics in the Oral Health education of CHAs, because the processes 
of dental growth and development are element about which knowledge is relevant for the physical development and evolution of the patient as a whole. The chronology of tooth eruption serves as indicator of a series of biologic occurrences, and may be influenced by diverse genetic and environmental factors ${ }^{32}$.

In the question approaching the risk factors for caries, statistically significant difference was shown with regard to the sample of the group of CHAs connected with a FHU with and without an OHT. The mean score obtained by the sample of CHAs connected with a FHU with an OHT was higher than that presented in the study of Bianco $^{13}$. That is; this may lead to the CHAs with OHT to inform the population better about the main risk factor for caries lesions.

In the same question, the category of expected response was checked by $53.09 \%$ of the CHAs of the Group with an Oral Health Team, over half the interviewees of this group. Whereas in the group of CHAs without an Oral Health Team, $32.10 \%$ checked the expected response to the question. The fact that CHAs without an Oral Health Team lack such primordial knowledge for the correct guidance about non cariogenic diet, causes concern. There are over $65 \%$ of the CHAs belonging to this group, who do not guide the population in their territory about this risk factor due to lack of knowledge. Therefore, one could believe that this basic Oral Health topic is passed on by the OHT to the CHAS in the FHU.

Another relevant topic approached in this study refers to the problem of halitosis, considered a negative factor for the individual's self-image, having impact on confidence and leading to avoiding social contact ${ }^{33}$. The percentage of CHAs who checked the expected response was $77 \%$ for the group of CHAs without an Oral Health Team and 75\% for the group with an Oral Health Team. This is a percentage a little below that found in the study of Bianco ${ }^{13}$, whose sample of CHAs obtained $80 \%$. The lack of knowledge about how to prevent halitosis potentiates the development of associated clinical manifestations that may limit the quality of life. Oral Health education must be related to the physical and psychological aspects of the human being ${ }^{34}$.

Two questions in the questionnaire were related to knowledge about gingival conditions. Neves et al. ${ }^{35}$ developed a study about the prevalence and severity of gingivitis in a population with a low socioeconomic level. They reported that in Brazil, studies have demonstrated that gingivitis and periodontitis present higher prev- alences in populations with the worst socioeconomic indicators.

In the present study, the CHAs with OHT demonstrated excellent knowledge when they answered the question about the eventual development of gingival bleeding, and also when they answered about the preventive measures to adopt to improve this condition. Whereas the CHAs without OHT presented knowledge that was a little inferior when compared with that of the other group. It is suggested that the OHT has a positive influence on these results, after all, guidance about oral health is one of the practices most performed by dentists within the FHU. Emmi and Barroso ${ }^{36}$ evaluated the oral health actions in the Family Health Program in the district of Mosqueiro/Pará, and when they asked users about the factors that led to improvement, and which they considered relevant after the inclusion of OHTs, they observed that the most cited factors were guidance about oral hygiene, whether delivered in lectures, home visits or during the dental consultation itself.

This study differs from others in which knowledge of the cause is interlaced with the practice for combating gingival problems, because a high percentage of CHAs pointed out the importance of brushing and dental floss. This result demonstrates that the CHAs are prepared to guide the users about the use of these important preventive tools in oral health. This is a relevant fact, because the population still needs information about these important oral health tools.

The need for endodontic treatment was also a target question in this study. The results were identical for the two groups. The total score of the groups was $320(98.76 \%)$ out of the 324 (100\%) they could attain.

Two studies ${ }^{13,14}$ used the same question with the same response alternatives, in which they found substantial, but a lower level of knowledge than that found in the present study. In the research of Frazão and Marques ${ }^{14}, 90.6 \%$ of the sample of CHAs of their study knew that untreated caries lesions lead to endodontic problems. In the study of Bianco ${ }^{13}$, the CHAs of Porto Velho/ Rondônia, attained a maximum score of 1159 $(88.9 \%)$ out of the possible 1304 (100\%). The knowledge of SUS users, transmitted to them by the CHAs, informing that untreated caries lesions may develop into endodontic problems, may lead to a greater number of users seeking dental treatment and adhesion to treatment in the FHU. In the municipality of Piracicaba/SP, endodontic treatment is referred to Secondary Care at the 
Center of Dental Specialties, according to a waiting list with an age limit for the endodontic treatment of molar teeth. Therefore, if these users were instructed to seek the FHU dental service in the initial stages of caries lesion, they would not need to be referred to Secondary care, thus easing the flow to this type of treatment.

The following question evaluated knowledge bout dental treatment for pregnant women. The CHAS connected with a FHU without an OHT, as a set, attained an absolute score equal to 154 out of a possible 162. Therefore, in terms relative to performance, they attained $95.01 \%$. Whereas the CHAs connected with a FHU with an OHT obtained a percentage of $99.38 \%$, a numerically higher percentage than that found in the study of Bianco ${ }^{13}$. In the study of Moimaz et al. ${ }^{37}$, it was shown that $75 \%$ of the pregnant women had received no guidance whatever about the importance of dental care during pregnancy. The 25 (25\%) who received guidance responded that they were instructed mainly by the workers at the health post (40\%), family, friends and husband (24\%), dentist (16\%), posters at the health post $(12 \%)$ and doctor $(8 \%)$. These results show the importance of health post professionals guiding pregnant women about oral health promotion aspects. The same authors, in their study added that the need to include the dental surgeon in the Prenatal care team has become evident, thus providing the team with training to provide basic information in the area of dentistry, and to act as a multidisciplinary team to care for pregnant women, with the use of educational and preventive methods.

The recognition of fluoride as an important product for Oral Health was identified in this study. The percentage of individuals who checked the expected response was exactly equal in the two groups, i.e., $92.12 \%$. More positive results were presented In this study, than in that of Martins et al. ${ }^{38}$, in which fewer than half the respondents affirmed that fluoride was positive not only for children, but for their parents as well.

Factors that predispose persons to the appearance of oral cancer was the subject dealt with in the last question of the questionnaire applied. Among the oral pathologies, neoplasms have drawn attention due to their growing incidence. In Brazil, cancer of the mouth is ranked seventh among all the cancers diagnosed. Estimates of the National Cancer Institute (INCA), for the year 201223439,990 new cases of cancer in the oral cavity in men, and 4,180 cases in women ${ }^{39}$.

The results found in this study point out good knowledge of the CHAs about the risk factor most related to oral cancer which, among the categories, the expected response would be: "excess consumption of alcohol and tobacco". In the group of CHAs connected with a FHU without OHT, $85.18 \%$ of the individuals checked the expected response. Whereas in the group of CHAs connected with a FHU with an OHT, this percentage was $90,12 \%$ of the individuals.

In the study of Oliveira et al. ${ }^{40}$, the object of which was to evaluate the knowledge of community health agents (CHAs) in Itajaí/Santa Catarina, about cancer, the results pointed out that in four of the five questions of the cognitive domain, the level of knowledge was unsatisfactory. The topic about risk factors was the one in which the best performance was obtained.

The significant difference between the two groups found in the present study, suggests that the OHT may have an influence on the CHAs' knowledge about Oral Health. However, the observations documented in the present study showed the importance of the role of the agent forming the OHT, which in the majority of instances, is composed of the Dental Surgeon and Oral Health Assistant, for improvement in the CHAs knowledge about Oral Health. This role may be related to the greater attention provided through conversation, with the intention of creating closer ties that may be acquired by OHTs showing confidence in, commitment to and respect for the CHAs.

Consequently, it is necessary for educational dental programs to be carried out, but it is imperative that the needs of the population are previously surveyed and interpreted, with particular regard to the level with less access to dental health services. Almeida ${ }^{41}$ also agreed. and in this context added that a strategy to obtain good results is to make use of the CHAs.

To Furlan ${ }^{42}$, the CHAs are outstanding persons within the present assistential model, and must receive continual training. Therefore, for the quality of the work process, it is essential for these CHAs to be trained to perform their role in a safe manner, in order to transmit correct information to the families.

Therefore it is necessary to use learning strategies that favor the education of these workers, and introduce continuous and permanent education into their work process. In spite of the CHAs developing a complex type of work, mainly characterized by the educational dimension, in general their professional education has been characterized by precarity and 
diversity. This is because, since the time of implementation of the Community Health Agent Programs (CHAPs), the Ministry of Health has established, as criterion of schooling for this job, the abilities to read and write ${ }^{43}$. Professional education is, in general, restricted to the training for work performed by the nurse-supervisor, in the case of CHAPs, or by the FHU team, operating in a distinct manner in the diverse municipalities who have adopted the Family Health Strategy. Therefore, the work of CHAs may mistakenly be understood as being easy. However, in the link with the community, the CHAs develop complex actions by the labor and subjective qualities expected; need to put into operation communicational processes of an educational nature, as in the case of guidance provided during home visits, or in the negotiation of conflicts between the community and the service, in search of opportunities for attention and care ${ }^{44}$.

Tomaz $^{45}$ has affirmed that "the process of qualification of the CHAs is still destructured, fragmented, and in the majority of instances, insufficient for developing the new competences necessary in order to enable them play their role adequately". It has therefore become necessary for the CHAs to be duly trained and qualified to perform technical procedures in oral health, such as oral hygiene techniques, early detection of caries, periodontal disease and oral cancer, among others, on pain of compromising the quality and effectiveness of actions developed ${ }^{17}$.

However, in 2003, in a movement of transformation of the area of Health, reorganization of the Ministry occurred, with the creation of the Secretary for the Management of Work and Education in Health ("Secretaria de Gestão do Trabalho e da Educação na Saúde (SGTES)". Therefore, in February, 2004, this new agency instituted the National Policy of Permanent Education in Health ${ }^{46}$, a National Health System (SUS) strategy for the education and development of workers for the sector, considering that as far back as the Federal Constitution of 1988 (Clause II, of Article 200), the competence to order education in the area of health was attributed to SUS. It is believed that after 10 years of the National Permanent Education in Health policy, the process of qualification of CHAs is more structured to develop the new competences necessary for them to adequately perform their role.

However, Mialhe et al. ${ }^{47}$, in a study conducted in Piracicaba/SP, pointed out that training programs with Oral Health Content, offered by the Primary Care Coordinators, were the form of contact of CHAs connected with the FHU without an OHT. According to this author, many CHAs did not perform Oral Health Education activities, or did so sporadically, due to the fact that they had not been trained for this. However, in municipalities where OHT had already been incorporated, it was observed that the CHAs presented better skills and resourcefulness to develop topics in Oral Health in the community, because they continually learned from the dental surgeon of the Team ${ }^{48}$.

Therefore the Dental Surgeon must form closer ties with the group of CHAs. The weekly team meeting, which forms part of the FHU management, may be an important time for CHAs to obtain continuous education and for planning of learning about oral health. However, for this to occur, it is necessary for the discipline of Collective Health, which already forms part of the curricular grid in dentistry courses, to use approaches that qualify the dental surgeon to be a forming agent and disseminator of Oral Health, with focus on social programs, whatever his/her specialty may be.

With regard to the limitations of this study, it has been a cross-sectional study, and thus, the results presented hear cannot be taken as cause and effect.

Hypotheses were raised in an attempt to explain the results found, however, they have not been tested, but they may guide new studies with regard to CHAs. The short period for data collection was also a limiting factor, a fact that made it impossible for the researcher to return to the same FHU again to interview the CHAs that were absent the first time, thus presenting a high percentage of losses (34.0\%).

Nevertheless, the present study was shown to be coherent with the present perspective of present approaches to health education, based on constructivism, interactionism, on problematizing teaching-learning methodologies, to the extent to which it allows the offer of training processes constructed in a singularized manner, and which take into account all the factors that have impact on the effectiveness of learning.

It was concluded that knowledge about the oral health/disease process, of the CHAs connected with a FHU with an OHT was better when compared with that of CHAs connected with a FHU without an OHT. 


\section{Collaborators}

GR Gouvêa, MAV Silva, KL Cortellazzi, AC Pereira, FL Mialhe and LM Guerra participated equally in all the stages of preparing the article.

\section{Acknowledgments}

The authors thank the Community Health Agents and Oral Health Coordinator of Piracicaba-São Paulo, Brazil.

\section{References}

1. Brasil. Ministério da Saúde (MS). Portaria MS/GM n ${ }^{\circ}$ 2.488 de 21 de outubro de 2011. Aprova a Política Nacional de Atenção Básica, estabelecendo a revisão de diretrizes e normas para a organização da Atenção Básica, para a Estratégia Saúde da Família (ESF) e o Programa de Agentes Comunitários de Saúde (PACS). Diário Oficial da União 2011; 24 out.

2. Brasil. Ministério da Saúde (MS). Departamento de Atenção Básica. Saúde bucal. Brasília: MS; 2008. (Caderno de atenção básica, n. 17).

3. Witmer A, Seifer SD, Finocchio L, Jeslie J, O’Neil EH. Community health workers: integral members of the health care work force. Am J Public Health 1995; 85(8):1055-1058.

4. Livingston A, Tomedi A, Campbell A, Morales C, Mwanthi MA. A Community Health Worker Home Visitation Project to Prevent Neonatal Deaths in Kenya. J Trop Pediatr 2012; 59(1):64-66.

5. Chowdhury AMR, Chowdhury S, Islam N, Islam A, Vaughan JP. Control of tuberculosis by community health workers in Bangladesh. Lancet 1997; 350(9072):169-172.

6. Harris MJ, Haines A. The potential contribution of community health workers to improving health outcomes in UK primary care. J R Soc Med 2012; 105(8):330335.

7. Schneider H, Hlophe H, Rensburg D van. Community health workers and the response to HIV/AIDS in South Africa: tensions and prospects. Health Policy Plan 2008; 23(3):179-187.

8. Brasil. Lei $n^{\circ} 10.507$, de 10 de julho de 2002. Cria a profissão de Agente Comunitário de Saúde e dá outras providências. Diário Oficial da União 2002; 10 jul.

9. Nascimento EPL, Correa CRS. O agente comunitário de saúde: formação, inserção e práticas. Cad Saude Publica 2008; 24(6):1304-1313.

10. Galavote HS, Prado TN, Maciel ELN, Lima RCD. Desvendando os processos de trabalho do Agente Comunitário de Saúde nos cenários revelados na Estratégia Saúde da Família no município de Vitória (ES, BRASIL). Cien Saude Colet 2011; 16 (1):231-224.

11. Souza DS, Cury JA, Caminha JAN, Ferreira MA, Tomita NE, Narvai PC. A Inserção da saúde bucal no Programa de Saúde da Família. Rev Bras Odontol 2001; 2(2):7-29.

12. Sanglard-Oliveira CA, Werneck MAF, Lucas SD, Abreu MHNG. Atribuições dos Técnicos em Saúde Bucal na Estratégia Saúde da Família em Minas Gerais, Brasil. Cien Saude Colet 2013; 18(8):2453-2460.

13. Bianco LC. Avaliação de conhecimentos em saúde bucal de agentes comunitários de saúde (ACS) e usuários do SUS de Porto Velho [dissertação]. Taubaté: Universidade de Taubaté; 2010.

14. Frazão P, Marques D. Influência de Agentes Comunitários de Saúde na percepção de mulheres e mães sobre conhecimentos de saúde bucal. Cien Saude Colet 2006; 11(1):131-144.

15. Santos CRI. O agente comunitário de saúde como ator na promoção de saúde bucal no programa de saúde da família de Rio Branco [dissertação]. São Paulo: Universidade de São Paulo; 2010.

16. Trapé CA, Soares CB. Educative practice of community health agents. Rev Latino-am Enfermagem 2007; 15(1):141-149. 
17. Nunes MO, Trad LB, Almeida BA, Homem CR, Melo MCI. O agente comunitário de saúde: construção da identidade desse personagem híbrido e polifônico. Cad Saude Publica 2002; 18(6):1639-1649.

18. Instituto Brasileiro de Geografia e Estatística (IBGE). Banco de Dados. Cidades. [acesso 2013 ago 20]. Disponível em: http://www.ibge.org.br.

19. Berlinguer G. Bioética cotidiana. Brasília: Ed. UnB; 2004.

20. Gil AC. Métodos e técnicas de pesquisa social. 6a Ed. São Paulo: Atlas; 2008.

21. Vasconcelos M, Cardoso AVL, Guimarães MHNA. Os desafios dos Agentes Comunitários de Saúde em relação à saúde bucal em município de pequeno porte. Arquivos em odontologia 2010; 45(2):98-104.

22. Escorel LS, Giovanella MH, Mendonça M, Senna MCM. O Programa de Saúde da Família e a construção de um novo modelo para a atenção básica no Brasil. Rev Panam Salud Publica 2007; 21(2):164-176.

23. Mota RRA, David HMSL. A crescente escolarização do agente comunitário de saúde: uma indução do processo de trabalho? Trab Educ Saude 2010; 8(2):229-248.

24. Brasil. Lei n. 11.350 de 5 de outubro de 2006. Define que as atividades de Agente Comunitário de Saúde e de Agente de Combate às Endemias. Diário Oficial da União 2006; 5 out.

25. Bachilli RG, Scavassa AJ, Spiri WC. A identidade do agente comunitário de saúde: uma abordagem fenomenológica. Cien Saude Colet 2008; 13(1):51-60.

26. Lino MM, Lanzoni GMML, Albuquerque GL, Schveitzer MC. Perfil socioeconômico, demográfico e de trabalho dos Agentes Comunitários de Saúde. Cogitare Enferm 2012; 17(1):57-64.

27. Marques DS. Impacto de uma capacitação de Agentes Comunitários de Saúde na promoção da Saúde Bucal [dissertação]. Santos: Universidade Católica de Santos 2005.

28. Ursine BL, Trelha CS, Nunes EFPA. O Agente Comunitário de Saúde na Estratégia Saúde da Família: uma investigação das condições de trabalho e da qualidade de vida. Rev Bras Saúde Ocup 2010; 35(122):327-339.

29. Ferraz L, Aerts DRGC. O cotidiano de trabalho do agente comunitário de saúde no PSF em Porto Alegre. Cien Saude Colet 2005; 10(2):347-355.

30. Losso EM, Tavares, MCSJY. Urban CA. Cárie precoce e severa na infância: uma abordagem integral. J Pediatr 2009; 85(4):295-300.

31. Barba FC. Percepção e atuação de Agentes Comunitários de Saúde em relação à Saúde Bucal [dissertação]. Brasília: Universidade de Brasília; 2009.

32. Haddad AE. A erupção dos dentes decíduos e sua relacão com o crescimento somático [tese]. São Paulo: Universidade de São Paulo; 2001.

33. Suzuki N, Yoneda M, Naito T, Iwamoto T, Hirofuji T. Relatioship Between halitosis and psychologic satatus. Oral Surg Oral Med Oral Pathol Oral Radiol Endod 2008; 106(4):542-547

34. Elias M. Ferriani M. Historical and social aspects of halitosis. Rev Latino-am Enfermagem 2006; 14(5):821823.
35. Neves AM, Passos IA, Oliveira AFB. Estudo da prevalência e severidade de gengivite em população de baixo nível socioeconômico. Odontol Clin-Cient 2010; 9(1):65-71.

36. Emmi DT, Barroso RFF. Avaliação das ações de saúde bucal no programa saúde da família no distrito de Mosqueiro (Pará). Cien Saude Colet 2008; 13(1):35-41.

37. Moimaz SAS, Rocha NB, Saliba O, Garbin CAS. O acesso de gestantes ao tratamento odontológico. Rev Odontologia da Universidade Cidade de São Paulo 2007; 19(1):39-45

38. Martins CC, Bonato KT, Valério DS, Leite FRM, Paiva SM Vale MP. Efetividade de uma técnica educativa na aquisição de conhecimentos por pais sobre uso racional do flúor. Rev Odonto Ciência 2006; 21(52):105-111.

39. Instituto Nacional de Câncer (INCA). Estimativa 2012: incidência de câncer no Brasil. Brasília, 2012. [acessado $2013 \mathrm{dez}$ 1]. Disponível em: http://www.inca.gov.br/ estimativa/2012/index.asp?ID=5.

40. Oliveira, LK, Ozelame SB, Dalcegio S, Philippi CK, Bueno RN, Bottan ER. Agente comunitário de saúde e a prevenção do câncer bucal. Salusvita 2012;31(2):141151.

41. Almeida HSS. A educação continuada como um mecanismo de transformação para os Agentes Comunitários de Saúde e a Equipe de Saúde Bucal - Relato de experiência. [dissertação]. Formiga: Universidade Federal de Minas Gerais; 2011.

42. Furlan PG. Veredas no território: análise de agentes comunitários de saúde [dissertação]. Campinas: Universidade Estadual de Campinas; 2008.

43. Brasil. Projeto de lei no 3.604, set. 1997. Dispõe sobre o exercício da profissão de agente comunitário de saúde e dá outras providências. Brasília: Câmara dos Deputados; 1997.

44. Morosini MV, Corbo Ad, Guimarães CC. O Agente comunitário de saúde no âmbito das políticas voltadas para a atenção básica: concepções do trabalho e da formação profissional. Trab Educ Saúde 2007; 5(2):261280 .

45. Tomaz JBC. O agente comunitário de saúde não deve ser um "super-herói". Interface (Botucatu) 2002; 6(10): 84-87.

46. Brasil. Ministério da Saúde (MS). Portaria no 198/GM/ MS, de 13 de fevereiro de 2004. Institui a Política Nacional de Educação Permanente em Saúde como estratégia do Sistema Único de Saúde para a formação e o desenvolvimento de trabalhadores para o setor. Diário Oficial da União 2004; 14 fev.

47. Mialhe FL, Lefrèvre F, Lefrèvre AMC. O Agente Comunitário de Saúde e suas práticas educativas em Saúde Bucal: uma avaliação qualiquantitativa. Cien Saude Colet 2011; 16(11):4425-4432.

48. Rodrigues AAAO, Santos AM, Assis MMA. Agentes comunitários de saúde: sujeito da prática em saúde bucal em Alagoinhas. Cien Saude Colet 2010; 15(3):907-915.

Article submitted 05/26/2014

Approved 07/23/2014

Final version submitted 08/11/2014 
